\title{
Malaysia-Indonesia Relations before and after 1965: Impact on Bilateral and Regional Stability (Note 1)
}

\author{
Mohd. Noor Mat Yazid ${ }^{1}$ \\ ${ }^{1}$ Programme of International Relations, School of Social Sciences, Universiti Malaysia Sabah, Kota Kinabalu, \\ Malaysia
}

Correspondence: Mohd. Noor Mat Yazid, Programme of International Relations, School of Social Sciences, Universiti Malaysia Sabah, Locked Bag 2073, 88999 Kota Kinabalu, Sabah, Malaysia. Tel: 60-12-868-0362. E-mail: mohdnoory2011@yahoo.co.uk

Received: August 18, 2013 Accepted: October 28, 2013 Online Published: November 29, 2013

doi:10.5539/jpl.v6n4p150

URL: http://dx.doi.org/10.5539/jpl.v6n4p150

\begin{abstract}
The main discussion in this paper is to determine the Indonesia-Malaysia relations during the period before and after 1965 and its impact on bilateral and regional stability in the South East Asian region. The bilateral relations during the period before 1965 was coloured by the conflict and hostilities. The bilateral relations of both countries had changed after 1965 from conflict and hostilities to cooperation and harmonious. The changes of the bilateral relations were strongly related to the role played by the American and Indonesian pro-democratic leaders, Suharto and his supporters. The improvement of the bilateral relations between Indonesia and Malaysia after 1965 was due to the strong support by American power which had paved the way to the formation of ASEAN in August 1967. The changes in the bilateral relations between Indonesia and Malaysia have contributed to enhance regional stability in the Southeast Asian region.
\end{abstract}

Keywords: The United States, Soviet Union, bilateral relations, Southeast Asia, ASEAN, regional organisation, stability

\section{Introduction}

This paper discusses the Malaysia-Indonesia relations before and after 1965 and its impact on bilateral and regional stability. Why was the year of 1965 became the turning point in the relations of both countries? What is the impact of the bilateral relations to the regional stability? The period before 1965 was coloured by the conflict and hostilities, but the period after 1965 was coloured by peace and cooperation. The discussion in this paper is divided into three parts; first part is the phase of conflict 1961-1965; the second part is the phase of peace and cooperation period 1966-1971 and; third part is the impact of the bilateral to the regional stability. The main objective of this paper is to explain the factors that contributed to; the different characters of relations during both phases of relations (before and after 1965) and the impact to the bilateral relations upon regional stability (i.e. South East Asia region) after 1965. This paper concludes that the event on $30^{\text {th }}$ September 1965 was important for the emergence of 'new order' Indonesia under Suharto, the formation of ASEAN and regional stability in the South East Asian region. It is put forth that it is impossible to achieve any stability in the South East Asian region without the democratic leaders in Indonesia and the formation of ASEAN in 1967.

\section{Phase of Conflict in the Indonesia-Malaysia Relations (1961-1965)}

During period of 1961-1965 the relations between Malaysia and Indonesia were coloured by the hostilities, conflict and confrontation. (Note 2) The Malaysian Federation proposal by Tunku Abdul Rahman (Prime Minister of Federation of Malaya) in May 1961 consisted of Federation of Malaya, Singapore, Sarawak, Brunei and Sabah (formerly called British North Borneo) raised new issues and conflict in the Malaysia-Indonesia relations.

In the eyes of the Sukarno Government of Indonesia, the Federation of Malaysia was a form of a neo-colonialism, i.e. the way for the British to control and maintain her political and economic power in the Southeast Asian region after World War II ended. Sukarno preferred 'pure independence' without external power interference in internal and external policy of a state when a state gained independence from European colonial masters. To him, the colonial powers should not interfere in their former colonies once they were independent. His idea of 'pure independence' referred generally to the former colonies in Asia and Africa, and specifically to Britain in Malaysia 
and the Netherlands in Indonesia. Other Western powers (especially The United States) also should not interfere in the Third World affairs. Third world countries should be able to make decisions independently in their internal and external policies.

Sukarno's confrontation policy towards Malaysian Federation did not only confront with Malaysia, but also with Great Britain and the Americans. The Americans and Great Britain had economic, political and strategic interests in the Malaysian region. Indonesia too, was an important country in the region and the Americans needed to consider Indonesia in achieving the stability in the region.

Sukarno's Indonesia in the early 1960s had close relations with Soviet Union, China (Note 3) and other communist countries. (Note 4) The international political structure in the 1960s gave advantages to Indonesia who had close relations with China. China and Soviet Union gave their support to Indonesia in the Indonesia-Malaysia conflict based on the ideological and East-West rivalry in the bipolar world structure. With strong support from China and Soviet Union, (Note 5) Sukarno launched the confrontation policy towards Malaysia in September 1963. (Federation of Malaysia was formed on $16^{\text {th }}$ September 1963 with strong support from the West, especially Great Britain, Australia and the United States).

The internal situation and political structure under Sukarno's administration had also influenced Sukarno to launch the confrontation policy towards Malaysia in 1963. (Note 6) The successful culmination of West Irian issue in 1962 gave moral and emotional support to the Sukarno administration. His government hoped that they could increase another territorial acquisition, i.e. Malaysian region after the West Irian was settled. The West Irian campaign had increased the economic burden on Indonesia. (Note 7) The Indonesian external debts were still unsettled and West Irian campaign contributed to the serious problems within the Indonesian economy in early 1960s.

The creation of another national issue (i.e. 'Crush' Malaysian campaign) (Note 8) was important for President Sukarno as a political 'escapism' for the Indonesian masses to distract them from domestic problems. Sukarno could make another promise to his masses that Indonesia's economic and social problems could be settled once the Malaysian issue ended. (Note 9) With the confrontation against an external power (i.e. confrontation with Malaysia), Sukarno could rally Indonesian mass population behind him. He used this external policy for the internal political advantage.

The position and role played by the PKI (Partai Komunis Indonesia=Indonesian Communist Party) (Note 10) is also significant in understanding the confrontation decision towards Malaysia. The coalition of PNI-NU-PKI had greatly influenced the Indonesian foreign policy decision since early 1960s to lean towards the communist bloc. The banning of Masjumi (Madjelis Sjuro Muslimin Indonesia) in 1960 following earlier clashes between Masjumi and PNI (Partai National Indonesia, Indonesian National Party) leaders in late 1950s had caused the PKI to be stronger. Masjumi was known for its moderate approach which was different from PKI. Masjumi had disagreed when Sukarno was perceived to be too lenient with communists at domestic level, and closer with communist bloc at the international level.

The resignation of Mohd Hatta as a vice-president of Indonesian in 1956 created further imbalance in Indonesian foreign policy between the West and communist countries. Hatta was pro-West in his policies. After his resignation, there were no balances between West-East policies and the Java and non-Java influences in Indonesian politics. The leaders from Java who were generally pro-communist in foreign policy aspects dominated Indonesian national politics during the period before 1965. The regional rebellion in 1958 was the peak of the disagreement between Masjumi and Sukarno.

When PKI joined the political coalition with Sukarno, it made Sukarno stronger, but by then the Indonesian foreign policy had leaned further towards the communist bloc. On the other hand, the Federation of Malaysia was seen as a 'pro-West' plot and they influenced Sukarno further to launch the confrontation against the new Federation. PKI Indonesian was the first party in Indonesian to condemn the Malaysian Federation. During the early years of Malaysian Federation proposal, the Indonesian Government (Foreign Minister Subandrio) did not raise any objection. However, 'the objection started after the PKI raised the 'Malaysian issue' as an important issue in Indonesian foreign policy.

The confrontation policy towards Malaysia ended in 1966. The change in Indonesian foreign policy began with the fall of Sukarno's regime and the removal of PKI influence in Indonesian politics. The PKI was destroyed in March 1966 by the new regime under Suharto. The rising of the new regime in Indonesia, i.e. 'the new order' administration under President Suharto after 1965 gave a great impact to the Indonesian foreign policy. 
During the confrontation period 1963-1966, Malaysia was fully supported by Great Britain, the Commonwealth Countries (especially Australia, New Zealand and Canada) and then the United States. (Note 11) The conflict between both countries during the years 1963-1966 was not solely the conflict between the two Southeast Asian neighbours, but was an international conflict that involved both sides of hegemonic powers, i.e. the Americans and Soviet Union and China. (The chronology of the international conflict between Communist-capitalist blocs (the United States-Soviet Union/China communist) and the confrontation between Indonesia and Malaysia, can be referred in the table 1 below). The United States, Great Britain, Australia, New Zealand, Canada and other Commonwealth countries gave their support to Malaysia, and on the other side, China and Soviet Union give their support to Indonesia. (Note 12)

It became important for the Americans power to become involved in the conflict because Indonesia is rich with natural resources (especially oil), the biggest country in Southeast Asia and located in a strategic location within international trade routes. (Note 13) Indonesia is important for the American economic and political power configuration in Southeast Asian region. Success in controlling Indonesia was an important factor in stabilising the American instability in Southeast Asian region in the 1960s.

In maintaining the American influence in Asia Pacific region (especially in Southeast Asia), the American role in Indonesian affairs and in domestic politics is seen as important. The political situation in the Cold War era and the communist expansion in the Asian region needed the American intervention as a balancer and also to contain the Soviet hegemony and China's communist expansion in the region. The Americans interference in Indonesia and the Malaysia affairs in 1960s were important to improve the stability in the Southeast Asian region. The American power needed Malaysia and Indonesia in facing his non-stable condition in Southeast Asia region. Without co-operation from Indonesia, and serious problems in Vietnam, it would weaken and destroy the American influence in Southeast Asia. The American power played a significant role of co-operating with Indonesia and Malaysia to stabilise the conditions in both states.

The formation of ASEAN in 1967 was also important to anchor American power stability in the Southeast Asian region. The capitalist States in Southeast Asian were bound together under the U.S. umbrella. The conflict in Vietnam, and internal communist insurgency accelerated the capitalist States to seek the American umbrella. The Soviets, Vietnam and China could have eroded American influence in the region without the American umbrella.

Malaysia is one of the richest Asian countries. It is rich with natural resources (rubber, timber, palm oil, tin, petroleum and other minerals), has a strategic location and is an important international centre for business and trade. Singapore, apart from being an international trade and business centre, has the fourth largest port in the world. Both America and Great Britain had vast economic and strategic interests in both Malaysia and Singapore. The Federation of Malaysia would secure advantages from the West and simultaneously avoid the Communist influence over the Singapore, Sabah and Sarawak. (Note 14) With the new federation that was pro-West and anti-Communist, it would protect the Western economic interest in the Malaysian region as well.

Since the Asia Pacific region was under international struggle between two great powers, Soviet Union and the United States, Southeast Asia was very important for the Americans in terms of economic and political interests. After the victory of (communist) Mao Tse-Tung in China in 1949, Korean War in early 1950s and Vietnam War I 1954, it was clear that the Soviet Union and the communists were trying to expand and control the whole of East and Southeast Asian region. The United States would have to contain the expansionist policy of the communists (China and Soviet Union) (Note 15) in protecting its interests and providing 'public good' for that region. (Note 16) If the communist powers succeeded in asserting control over Malaysia and Indonesia, the position of the Western military and security in East Asia (Japan, South Korea and Taiwan) and other Southeast Asian countries (Thailand and The Philippines) would be in danger. (Note 17) In understanding the development and crisis between Indonesia and Malaysia in 1960s and 1970s, it is necessary to understand the economic and political developments in the international level as well, i.e. the power and sphere of influence rivalries between two great powers. The knowledge of the Soviet expansion and the American containment in Europe (Note 18) and Asia; and the structure of great power struggle, provides a background in understanding and analysing the conflict in Southeast Asian region, and especially between Indonesia and Malaysia relation. (see table 1 below).

Table 1. Chronology events of Malaysia-Indonesia relations and related issues before 1965

-17 August Indonesia proclaimed independence from the Netherlands. Sukarno was appointed 
1945-1949 Indonesian independence struggle from the Netherlands.

\begin{tabular}{|c|c|}
\hline 1946 & November 1946 French-Vietminh War begins (First Vietnam War) \\
\hline 1947 & March 1947 Truman Doctrine announced. \\
\hline \multirow{2}{*}{1948} & $\begin{array}{l}\text {-September } 1948 \text { Communist revolt in Madium, Indonesia (supported by Soviet Union) broke } \\
\text { out. Sukarno and Hatta put down the communists revolt without the assistance of Dutch forces. }\end{array}$ \\
\hline & $\begin{array}{l}\text {-The United States interpreted that the Indonesian government under Sukarno and Hatta was } \\
\text { anti-communist. }\end{array}$ \\
\hline & $\begin{array}{l}\text {-Mao Tse-tung won the Chinese Civil War in October } 1949 \text { (Mainland China became a } \\
\text { communist state). }\end{array}$ \\
\hline 1949 & $\begin{array}{l}\text {-China was divided into two blocs based on ideology; People's Republic of China } \\
\text { (Communists) and Republic of China (Taiwan), capitalists. }\end{array}$ \\
\hline
\end{tabular}

- Soviet's first nuclear explosion in September 1949.

-Indonesia gained formal independence on 27 December 1949 from the Netherlands.

\begin{tabular}{|c|c|}
\hline \multirow{6}{*}{1950} & $\begin{array}{l}\text {-China signed thirty years' treaty with Soviet Union (China-Soviet Alliance). Soviet will } \\
\text { provide } \$ 300 \text { million in credit to China. }\end{array}$ \\
\hline & $\begin{array}{l}\text { - In September } 1950 \text { Indonesia was formally admitted to the United Nations as the sixtieth } \\
\text { member. }\end{array}$ \\
\hline & -North Korean attack on South Korea-Korean War began in June 1950. \\
\hline & - Treaty of Peace and Security between the U.S and Japan signed on 8 September. \\
\hline & -Mutual defence treaty between the U.S. and the Philippines was signed on $30^{\text {th }}$ August. \\
\hline & $\begin{array}{l}\text {-Security Treaty among Australia, New Zealand and the U.S. (ANZUS) was signed on } 1 \\
\text { September. }\end{array}$ \\
\hline \multirow{3}{*}{1953} & -President Stalin died. \\
\hline & -Dwight Eisenhower had been elected as the U.S. president. \\
\hline & -Treaty of Mutual Defence between the U.S. and South Korea was signed on 1 October. \\
\hline \multirow{4}{*}{1954} & $\begin{array}{l}\text {-Geneva Conference } 1954 \text {. Vietnam provisionally divided into North Vietnam and South } \\
\text { Vietnam along } 17^{\text {th }} \text { parallel. }\end{array}$ \\
\hline & -North Vietnam became a Communist state. \\
\hline & $\begin{array}{l}\text {-Southeast Asian Treaty Organisation (SEATO) was created. The SEATO members are the } \\
\text { United States, Great Britain, France, Australia, New Zealand, the Philippines, Thailand and } \\
\text { Pakistan. }\end{array}$ \\
\hline & - Treaty of Mutual Defence between the U.S. and Taiwan was signed on 2 December 1954. \\
\hline \multirow{2}{*}{1955} & $\begin{array}{l}\text {-First Indonesian General Election. Indonesian Communists Party (PKI) obtained } 39 \\
\text { parliamentary seats or } 16.4 \% \text { of valid votes. }\end{array}$ \\
\hline & $\begin{array}{l}\text { - The Bandung Conference } 1955 \text { held in Bandung Indonesia in April 1955. Attended by } \\
\text { representative from } 29 \text { newly independent states from Asia and Africa, }\end{array}$ \\
\hline \multirow{2}{*}{1957} & $\begin{array}{l}\text { - Federation of Malaya gained independence from United Kingdom on } 31^{\text {st }} \text { August by peaceful } \\
\text { mean (negotiation). }\end{array}$ \\
\hline & $\begin{array}{l}\text { - Anglo-Malayan Defence Agreement was signed between Federation of Malaya and United } \\
\text { Kingdom in September } 1957 .\end{array}$ \\
\hline \multirow{2}{*}{1958} & -PRRI Rebellion in Padang, Sumatra and PARMESTA Rebellion in Celebes. \\
\hline & -PRRI was supported by the United States and Great Britain. \\
\hline 1960 & President Sukarno banned Masjumi political Party. \\
\hline 1961 & $\begin{array}{l}\text {-The formation of Association of Southeast Asia (ASA) included Malaya, the Philippines and } \\
\text { Thailand. }\end{array}$ \\
\hline
\end{tabular}


- President Khrushchev of Soviet Union visits Indonesia.

-Tunku Abdul Rahman, Prime Minister of Malaya raised the idea of the unification of Malaya, Singapore, Sabah, Sarawak and Brunei.

-A discussion in London between The British and Malayan Government $\left(20^{\text {th }}\right.$ to $22^{\text {nd }}$ of November). A joint statement was issued by the British and Malayan Governments, approving in principle the creation the Federation of Malaysia and announcing that a Commission would be set up to ascertain the views of the peoples of North Borneo and Sarawak.

1962 The confrontation on West Irian between Indonesia and the Netherlands settled

-November 1963, South Vietnam President Ngo Dinh Diem deposed and assassinated in coup.

- August 1963, meeting of Tunku Abdul Rahman, President Sukarno and Macapagal in Manila-brought the birth of MAPHLINDO.

1963 - The split between Soviet Union and The People's Republic of China.

- President Kennedy was assassinated.

- The Formation of the Federation of Malaysia on 16 September 1963.

-November 1963, South Vietnam President Ngo Dinh Diem deposed and assassinated in coup.

-The First Malaysian General Elections in Malaysia (after the formation of Malaysian Federation). Alliance Party won the election. The Opposition party (who supported Sukarno and

1964 unification with Indonesia) lost badly.

- Indonesian withdrew from the United Nations

- October 1964, Leonid Brezhnev replaced President Khrushchev.

- Kosygin went to Hanoi promising the resumption of the aid Khrushchev had cut.

1965

-February 1965 President Johnson approved operation Rolling Thunder, i.e. the systematic bombardment of North Vietnam.

-July 1965, President Johnson sent 100,000 combat troops to South Vietnam to fight Vietnamese communist.

\section{Phase of Co-operation in Indonesia-Malaysia Relations (1966-1971)}

The period after 1965 was totally different from the period 1961-1965 in Indonesia-Malaysia political relations. After 1965, the political relations between Indonesia and Malaysia were marked by friendship, harmony and co-operation. (Note 19) The new regime in Indonesia in 1967 reversed the old policy and type of political relationship with Malaysia. The pattern of Indonesian foreign policy and her relations with other countries also changed after 1965. (Note 20) The new government under President Suharto took the initiative to end the confrontation with Malaysia, and actively sought co-operation with Malaysia and other neighbouring Southeast Asian countries.

The formation and successful launching of a regional organisation in Southeast Asia was largely on account of the initiative and leadership role taken on by the 'new order' leaders of Indonesia, under President Suharto. (Note 21) ASEAN with Indonesia as an important member, the strong support given by the American, contributed to the success of ASEAN. (Note 22) Without Indonesian support, it would not have been possible to achieve harmony, co-operation and stability in the Southeast Asian region. (Note 23) The role played by the strong regional power (Indonesia) to obtain Southeast Asian political stability after 1967 cannot therefore be underestimated.

The change in relations between Indonesia with the American power, domestic political developments and domestic economic situation in Indonesia all contributed to the new phase of relations between Indonesian-Malaysian. (see table 2 below). The political and economic developments after 1965 were an important process of strengthening and consolidating the American position and stability in Southeast Asian region as well. This becomes evidently clear if the chronology of events in the table 2 is perused.

The changes in the relations between Malaysia and Indonesia after 1965 could be also clearly explained by understanding the changes in Indonesian domestic politics, (Note 24) and also in the changes of relations with the American power and the great role played by the Americans in the archipelago Southeast Asian regional affairs. (Note 25) Before 1966, the Americans failed to play an effective role in the Southeast Asian archipelago because 
of the President Sukarno idiosyncratic factor. President Sukarno had his own political agenda with his non co-operation policy with the Western countries.

Indonesian domestic politics under President Suharto was totally different with the period before 1966 (or since October 1965) under the President Sukarno administration. The political philosophy and internal Indonesian political party alliances between President Suharto and President Sukarno were entirely different. Suharto was an anti-communist and a more pragmatic person. The different character between the two leaders contributed to the pattern of the political party alliance in domestic politics. (Note 26) PKI was banned in March 1966, but the process of destroying communist party started very soon after $1^{\text {st }}$ of October 1965.

The Indonesian political development after $1^{\text {st }}$ October 1965 greatly strengthened the position of the Army in the nation affairs. With millions of PKI leaders and members killed without trial, the Army played an important role in Indonesian domestic politics and administration after 1965. The Army's political activities under General Suharto since 1965 was to strengthen the Army position and completely destroy the PKI.

The general election was held in 1971 when the army position in Indonesian politics was secured. In that general election, 'Golkar' under President Suharto leadership obtained a preponderant majority. Golkar obtained 236 seats out of 360. (Note 27) Other political parties also were allowed in the 1971 general elections, but their performance was very poor. Nahdatul Ulama obtained 58 seats, Parmusi (Parti Muslim Indonesia) 24 seats, PNI 20 seats, PSII 10 seats, Parkindo 7 seats, Catholic Party 3 seats and Perti (Pergerakan Tarbiyah Islamiah) 2 seats. (Note 28) With such majority, Golkar under President Suharto was strong and successful in creating a stable government.

The political parties' coalition under the Suharto administration differed from that under President Sukarno in 1950s. PNI party under Sukarno was not so strong and failed to form a strong and stable government in the mid 1950s. Sukarno therefore created a coalition with PKI to strengthen his position, which had caused dissatisfaction with Masjumi. PKI was a party that was not really accepted by the majority of the Indonesian population, especially the Muslims and the Army. This disagreement contributed to the political instability and social disharmony during the Sukarno era.

Table 2. Chronology events of Malaysia-Indonesia relations and related issues after 1965

\begin{tabular}{ll}
\hline 1965 & -Singapore withdrew from the Federation of Malaysia in August 1965. \\
\hline 1965 & -Indonesian Coup 1965 on $30^{\text {th }}$ September 1965. \\
\hline 1966 & -In March 1966 PKI was banned by the new order Indonesian (under President Suharto). \\
& -Suharto became acting President of Republic Indonesia. \\
\hline \multirow{2}{*}{1966} & -August 1966, Indonesia and Malaysia ceased all hostilities and renewed diplomatic ties. \\
& -On 11 August 1966, Indonesian Foreign Minister, Tun Adam Malik and Malaysian Deputy \\
& Prime Minister, Tun Abdul Razak ratified The Bangkok Accord in Jakarta. \\
\hline August 1967 & -The formation of Association of Southeast Asian Nations (ASEAN). \\
\hline \multirow{2}{*}{1968} & -January 1968, Vietcong guerrillas and North Vietnamese regular attacks on major South \\
& Vietnamese cities, indicated to U.S. that Vietnam war was far from won. \\
\hline May 1969 & -May Thirteen Incidents in Malaysia. The ethnic riot between Malay and Chinese ethnic. \\
\hline \multirow{3}{*}{1970} & -President Sukarno's death. \\
& -First Indonesian general elections under new order administration. \\
& -New Friendship Treaty between Malaysia and Indonesia was signed. \\
& -The ASEAN foreign minister approved the Kuala Lumpur declaration; ASEAN recognised \\
& the ZOPFAN (Zone Of Peace, Freedom And Neutrality). \\
& -The U.S. Secretary of State (Henry Kessinger) visits China (as a preparation for the President \\
& Nixon's official visit in 1972). \\
& -The United States returned Okinawa islands to Japan. \\
\hline & -President Nixon visited China and signed Shanghai Communiqué sealing rapprochement. \\
\hline
\end{tabular}


Indonesian domestic politics had influenced the pattern of the Indonesian foreign policy. The stronger and stable domestic political situation enabled the formulation of a more effective and successful Indonesian external policy. With the stable situation in domestic level after 1966, Indonesia could play a more important and effective leadership role in regional matters.

New order administration under President Suharto had improved relations with American and other Western powers. (Note 29) The United States and Japan drew closer to Indonesia after 1966 (since after September 1965). The motive behind the close relations with Japan and The United States was to achieve a more rapid economic recovery and national development. (Note 30) National development and economic stability were among the goals of the new order regime. (Note 31) With economic stability and greater opportunities to raise living standards the mass support and their confidence in the new regime could only be positive.

Indonesian domestic political stability under President Suharto after 1965 and the new direction of foreign policy were responsible for the new pattern of improved relationships between Indonesia and Malaysia. In this context the ideological factor, i.e. the democratic-capitalistic ideology after 1965 in Indonesian politics, and changes in leader perceptions were very influential in foreign policy decision and bilateral relations.

The Americans encouraged co-operation not only between Indonesia and Malaysia, but also among all of the ASEAN members. (Note 32) This co-operation within ASEAN in turn contributed to and further enhanced American influence in the Southeast Asian region. The co-operation between the ASEAN members gave positive advantages to Indonesia-Malaysia relations, improved economic achievement between both countries and other ASEAN nations and most importantly obstructed the communists expansion from China and Indo-China (especially Vietnam) to the ASEAN countries. (Note 33)

This regional association played a positive role in the American struggle for stronger position with the Soviets in the South East Asia and Pacific region. ASEAN was a bloc or barrier to the Soviet ambition in ASEAN countries. Indonesia as a leader in ASEAN was very anti-communist and her relations with China had frozen in October 1965 (just a few days after the Coup of September 1965). The co-operation between the United States and Indonesian regional power was successful in the period after 1967 until the collapse of the Soviet Union Empire in 1991.

\section{Discussion and Conclusion}

The period before and after 1965 was totally different in Malaysia-Indonesia relations. Before 1965 the relations were marked by hostilities and conflict. The domestic political situation in Indonesia had strongly influenced the bilateral relations. The event of September 1965, with the Indonesian Coup and changes in the domestic political situation in Indonesia, had paved the way to the 'new order' administration in Indonesia under the new leader, Suharto. Under the Suharto administration, Indonesian domestic and foreign policies had totally changed from those under Sukarno before 1965. Malaysia-Indonesia bilateral relations had improved dramatically. Suharto's foreign policy, which was pro-West, had influenced the dramatic changes in economic and political policies after 1965. The active role played by the Indonesian and the other South East Asian Nations paved the way for the formation of the new regional association (Association of South East Asian Nations, ASEAN) in August 1967. The main objective of the formation of ASEAN was to resolve the conflict between Indonesia and Malaysia, and also to bind all of the democratic-capitalist countries in the South East region (the Philippines, Thailand and Singapore) in facing common enemy (the spreading of communist) from Indochina. This regional organisation with Indonesia as a leader (it could be considered as a regional power) played a crucial role in creating new cooperation among the ASEAN members (Indonesia, Malaysia, Thailand, the Philippines and Singapore). Indonesia as the biggest countries is seen important in leading the regional association such ASEAN. Prior to 1967 there were two organisations formed the Association of South East Asia (ASA) and Malaya, the Philippines and Indonesia or MAPHILINDO, but without the active role played by Indonesian as the largest country in the South East Asian region, both regional organisations would have failed. Indonesian domestic political philosophy under President Sukarno which inclined towards communist bloc had influenced the Indonesian foreign policy decision. Before 1967 there was no means for the countries in the region to cooperate. The countries could only cooperate and create harmonious relations when the effective regional organisations (ASEAN) were formed. The formation of ASEAN in August 1967 was the turning point in the cooperation and harmonious relations among the ASEAN members. After 1967 the clear boarder between Communist bloc (in Indochina) and democratic-capitalist bloc (ASEAN countries) was created. The existing of clear boundary between ASEAN democratic and Indochina communist contributed to the clear policy in the bipolarity structure (Cold War) and useful in maintaining regional stability of South East Asia. The creation of ASEAN was quite similar with the formation of clear boarder of Western Europe (capitalist) and Eastern Europe (communist) during the bipolarity structure Cold War Era in Europe before 1989. Close relations and cooperation among the ASEAN members in 1970s and 1980s had greatly 
contributed to the regional stability. Brunei joined the ASEAN in 1984 (after gaining independence from Great Britain), followed by the Indochina countries (Vietnam, Cambodia and Laos) and Myanmar after the end of the Cold War in 1990. The increasing number of ASEAN members after the end of the Cold War is similar to the process of increasing members of European Union and NATO (from former communist states of Eastern European Communist) after the end of the Cold War. Currently ASEAN is one of the most successful regional organisation in the Asia Pacific region with ten members. The stability in the South East Asian region would not have been achieved had the communist influence was not curbed.

\section{References}

Crouch, H. (1972). Military Politics under Indonesia's New Order. Pacific Affairs, 42(2), 210-219.

Derkach, N. (1965). The Soviet Policy towards Indonesia in the West Irian and the Malaysian Disputes. Asian Survey, 5(11), 566-571. http://dx.doi.org/10.2307/2642136

Hindley, D. (1963). Foreign Aid to Indonesia and Its Political Implications. Pacific Affairs, 26(2), 107-119. http://dx.doi.org/10.2307/2754184

Hindley, D. (1964). Indonesia's Confrontation with Malaysia: A Search for Motives. Asian Survey, 4(60), 904-913. http://dx.doi.org/10.2307/3023528

Horn, R. C. (1973/74). Indonesia's Response to Changing Big Power Alignments. Pacific Affairs, 46(4), 516-533. http://dx.doi.org/10.2307/2755326

Jo, Y. H. (Ed.). (1978). U.S. Policy in Asia: An Appraisal of America's Role in Asia. Santa Barbara, CA: Clio Press.

Kroef, J. M. V. D. (1962). Indonesia's Economic Difficulties. International Journal, 27(4), 399. http://dx.doi.org/10.2307/40198893

Kroef, J. M. V. D. (1964). Singapore's Communist Fronts. Problems of Communism, 13(5), 53-66.

Kurus, B. (1993). Understanding ASEAN: Benefits and Raison D'Etre. Asian Survey, 28(8), 819-831. http://dx.doi.org/10.2307/2645090

Lee, P. P. (1992). The Indochinese Situation and the Big Powers in Southeast Asia: The Malaysian View. Asian Survey, 27(6), 516-523.

Leifer, M. (1966). Indonesia and Malaysia: The Changing Face of Confrontation. World Today, 22(9), 395-405.

McCloud, D. G. (1995). Southeast Asia: Transition and Modernity in The Contemporary World. Boulder; Westview Press.

Pollard, V. K. (1970). ASA and ASEAN, 1961-1967: Southeast Asian Regionalism. Asian Survey, 10(3), 249-254. http://dx.doi.org/10.2307/2642577

Roesnadi, S. O. (1973). ASEAN and the Great Powers. The Indonesian Quarterly, 1(4), 100-118.

Rudner, M. (1976).The Indonesian Military Economic Policy: The Goals and Performance of the First Five-Year Development Plan, 1969-1974. Modern Asian Studies, 10(2), 249-284. http://dx.doi.org/10.1017/S0026749X00005953

Spanier, J. (1985). American Foreign Policy since World War II. New York: CBS College Publishing.

Subritzky, J. (2000). Confronting Sukarno: British, American, Australia and New Zealand Diplomacy in the Malaysian-Indonesian Confrontation, 1961-1965. London: Macmillan Press Ltd.

Sukma, R. (1995). The Evolution of Indonesia's Foreign Policy. Asian Survey, 35(3), 304-315. http://dx.doi.org/10.2307/2645547

Suryadinata, L. (1990). Indonesia-China Relations. Asian Survey, 30(7), 684-687. http://dx.doi.org/10.2307/2644558

Suryadinata, L. (1990). Indonesia-China Relations. Asian Survey, 30(7), 682-684. http://dx.doi.org/10.2307/2644558 


\section{Notes}

Note 1. This paper was presented in The Symposium on Cultural Diplomacy in The Asia Pacific: The Application of Cultural Diplomacy in Fostering Relations, at Institute of Cultural Diplomacy, Berlin, Germany on 7-9 ${ }^{\text {th }}$ June 2013.

Note 2. Saravanamuttu, Johan. (1987). Malaysia's Foreign Policy, 1957-1980. in Ahmad, Zakaria (Ed.), (1987) Government and Politics of Malaysia. Singapore: Oxford University Press, pp. 128-160.

Note 3. Suryadinata, L. (1990). Indonesia-China Relations. Asian Survey, 30(7), 682-684.

Note 4. Hindley, D. (1963). Foreign Aid to Indonesia and Its Political Implications. Pacific Affairs. 36( 2), 107-119.

Note 5. Derkach, N. (1965). Soviet Policy towards Malaysia and West Irian Issue. Asian Survey, 5(11), 566-571

Note 6. Hindley, D. (1964). Indonesia's Confrontation with Malaysia: A Search for Motives. Asian Survey, 4(6), 904-913.

Note 7. Kroef, J. M.V.D. (1962). Indonesia's Economic Difficulties. International Journal, 17(4), 399.

Note 8. Indonesian foreign policy under President Sukarno to destroy the formation of new federation, Malaysia.

Note 9. Weatherbee, D. E. (1962). Indonesia and Malaysia; Confrontation in Southeast Asia. Orbis, Summer 1962, pp. 336-351.

Note 10. PKI was a legal political party in Indonesian political system before October 1965. In the first Indonesian General Election 1955, PKI was one of the major political parties which gained strong support from rural Indonesian voters.

Note 11. In the early period of Confrontation only the United Kingdom, Australia and New Zealand opposed Indonesian confrontation by sending defence forces to Malaysia. The United States still exercised an 'appeasement policy' towards Sukarno Indonesia. The United States changed this policy after Sukarno withdrew from the United Nations and strictly fought with the United States.

Note 12. For the explanation of Soviet Union policy towards Indonesia in the Confrontation see Derkach, N. (1965). The Soviet Policy towards Indonesia in the West Irian and the Malaysian Disputes. Asian Survey, 5(11), 566-571.

Note 13. See Subritzky, J. (2000). Confronting Sukarno: British, American, Australia and New Zealand Diplomacy in the Malaysian-Indonesian Confrontation, 1961-1965. London: Macmillan Press Ltd.

Note 14. Kroef, J.M.V.D. (1964). Singapore's Communist Fronts. Problems of Communism, 13(5), 53-66.

Note 15. The Soviet Union (not the China Communist) was viewed as the major communist threat to United States security interest in Asian region. See Fifield, R. H. (1973). Americans in Southeast Asia: The Roots of Commitment, p. 141.

Note 16. For the motives of communism containment, the American alliance network extended from Europe through Southeast Asia, surrounding the Eurasian heartland that was controlled by the Soviet Union and China. Added to the regional alliances were the bilateral treaties with Japan, South Korea, and Taiwan, as well as the Pacific Security Treaty also known as the ANZUS pact with Australia and New Zealand. NATO in Europe, CENTO (Central Treaty Organisation) in the Middle East and SEATO in Southeast Asia. All of those Security treaties were to contain communist expansion. See McCloud, D. G., (1995). Southeast Asia: Transition and Modernity inThe Contemporary World. Boulder: Westview Press, p. 162.

Note 17. Yung-Hwan Jo (ed.). (1978). U.S. Policy in Asia: An Appraisal of America's Role in Asia. Santa Barbara, CA: Clio Press, pp. 1-14.

Note 18. Spanier, J. (1985).American Foreign Policy since World War II. New York: CBS College Publishing, especially chapter 2 and chapter 4 .

Note 19. Sukma, Rizal. (1995). The Evolution of Indonesian's Foreign Policy. Asian Survey, 35(3), 310.

Note 20. Sukma, Rizal. (1995). The Evolution of Indonesia's Foreign Policy. Asian Survey, 35(3), 311-312.

Note 21. Leifer, M. (1966). Indonesia and Malaysia: The Changing Face of Confrontation. World Today, 22(9), 395-405. 
Note 22. Roesnadi, O. Sutomo. (1973). ASEAN and The Great Powers. The Indonesian Quarterly, 1(4), 20-21; and see also, Pollard, V. K. (1970). ASA and ASEAN, 1961-1967: Southeast Asian Regionalism. Asian Survey, 10(3), 254-255.

Note 23. See Kurus, Bilson. (1993). Understanding ASEAN: Benefits and Raison D’Etre. Asian Survey, 33(8), 819-831.

Note 24. Crouch, H. (1972). Military Politics under Indonesia’s New Order. Pacific Affairs. Summer 1972, pp. 210-219.

Note 25. Horn, R., C. (1973/74). Indonesia's Response to Changing Big Power Alignments. Pacific Affairs, 46(4), 516-533.

Note 26. Crouch, H. (1972). Military Politics under Indonesia's New Order. Pacific Affairs, 42(2), $214-216$.

Note 27. Pemilu (Pemilihan Umum or general elections), http://www.kpu.go.id/Sejarah1971.shtml p.2

Note 28. Pemilu, http://www.kpu.go.id/Sejarah/pemilu1971.shtmlp. 2

Note 29. Sukma, Rizal, (1995).The Evolution of Indonesia's Foreign Policy. Asian Survey, 35(3), 310-314; and see also Suryadinata, Leo, 1990. Indonesia-China Relations. Asian Survey, 30(7), 684-687.

Note 30. Horn, R. C. (1973/74). Indonesia's Response to Changing Big Power Alignment. Pacific Affairs, 46(4), 517.

Note 31. Rudner, M. (1976). The Indonesian Military Economic Policy: The Goals and Performance of the First Five-Year Development Plan, 1969-1974. Modern Asian Studies, 10(2), 250.

Note 32. Roesnadi, O. Sutomo, (1973). ASEAN and the Great Powers. The Indonesian Quarterly, 1(4), 21.

Note 33. Lee Poh Ping (1982). The Indochinese Situation and the Big Powers in Southeast Asia: The Malaysian View. Asian Survey, 22(6), 516-523.

\section{Copyrights}

Copyright for this article is retained by the author(s), with first publication rights granted to the journal.

This is an open-access article distributed under the terms and conditions of the Creative Commons Attribution license (http://creativecommons.org/licenses/by/3.0/). 